\title{
Secretory pattern of growth hormone regulates plasma concentration of pregnancy-associated murine protein-1 in the non-pregnant rat*
}

\author{
L. Eriksson, L. Carlsson-Bostedt $\dagger$, J. Oscarsson $\ddagger$, S. Edén $\ddagger$, T. Stigbrand $\dagger$ \\ and B. von Schoultz
}

Department of Obstetrics and Gynecology, University Hospital, S-901 85 Umea, Sweden; $\dagger$ Department of Physiological Chemistry, University of Umea, S-901 87 Umea., Sweden; and $\$$ Department of Physiology, University of Göteborg, S-400 33 Göteborg, Sweden

\begin{abstract}
Summary. Serum concentrations of pregnancy-associated murine protein-1 (PAMP-1) were followed in hypophysectomized adult female rats during treatment with oestradiol and continuous or intermittent human growth hormone (hGH). After hypophysectomy a rapid decrease in PAMP-1 values was recorded while concentrations of albumin and the acute phase $\alpha_{2}$-macroglobulin were unaffected. PAMP-1 values were completely restored by continuous infusion of hGH $(1.4 \mathrm{i} . \mathrm{u} . / \mathrm{kg} /$ day $)$. Neither the same dose of hGH given as two daily injections nor oestrogen replacement treatment had any effect. It is concluded that the serum concentration of PAMP-1 in the non-pregnant rat is regulated by the sexually dimorphic secretory pattern of $\mathrm{GH}$.
\end{abstract}

Keywords: pregnancy-associated protein-1; growth hormone secretion; rat

\section{Introduction}

Pregnancy and exogenous sex steroids greatly affect the circulating concentrations of several plasma proteins (Laurell \& Rannevik, 1979; Waites \& Bell, 1986). The human pregnancy associated $\alpha_{2}$-glycoprotein $\left(P A \alpha_{2} G, P Z P\right.$ SP3) is one example of a major pregnancy-associated plasma protein which is extremely sensitive to exogenous sex steroids (von Schoultz \& Stigbrand, 1982). This protein has a close structural relationship to $\alpha_{2}$-macroglobulin and has proteinase binding properties (Sand et al., 1985). The pregnancy-associated murine protein-1 (PAMP-1) and the acute phase $\alpha_{2}$-macroglobulin of the rat have been suggested as analogues to human PA $\alpha_{2} G$ (Hau \& Porstmann, 1984; Carlsson et al., 1985). The marked effects of pregnancy and oestrogens on the serum concentrations of these 'pregnancy-associated' proteins in man and rodents have been generally believed to reflect a direct effect of oestrogens on the liver or possibly other sites of protein synthesis (Hau et al., 1982; Sarcione et al., 1986). However, hypophysectomy of female mice resulted in a disappearance of PAMP-1 that was unaffected by oestrogen treatment (Hau et al., 1983). Continuous infusion of human growth hormone (hGH) to hypophysectomized female and intact male mice (Fröhlander et al., 1987) and intact male rats (Carlsson-Bostedt et al., 1987) increased the serum concentration of this protein, suggesting a role for $\mathrm{GH}$ in the regulation of the serum levels of PAMP-1.

Growth hormone secretion in the rat is markedly different in males compared to females. In male rats GH is secreted in episodic bursts at 3-4-h intervals with low or undetectable levels between peaks (Tannenbaum \& Martin, 1976), whereas female rats have a more continuous

*Reprint requests to: Dr B. von Schoultz. 
secretion with higher baseline values (Edén, 1979). A continuous infusion of GH by means of osmotic minipumps to hypophysectomized rats, thereby mimicking the female secretory pattern, has been shown to 'feminize' the hepatic concentration of prolactin receptors as well as hepatic steroid metabolism, whereas GH given intermittently was without effect (Mode et al., 1981; Norstedt, 1982).

In the present study we adopted this method, to mimic the sexually dimorphic secretory pattern of $\mathrm{GH}$, to elucidate further the role of $\mathrm{GH}$ in the regulation of serum concentrations of PAMP-1 in the rat. Serum concentrations were measured in hypophysectomized adult female rats during treatment with oestradiol and continuous or intermittent hGH. In addition serum concentrations of albumin and the acute phase $\alpha_{2}$-macroglobulin of the rat were analysed.

\section{Materials and Methods}

Animals. Female Sprague-Dawley rats, purchased from Alab Laboratories Ltd, Stockholm, Sweden, were maintained under controlled conditions of constant temperature $\left(24-26^{\circ} \mathrm{C}\right)$, humidity $(50-60 \%)$, and a $14 \mathrm{~h}$ light:10 h dark cycle (lights on at 06:00 h). Standard laboratory chow (Type R3: Ewos, Södertälje, Sweden) and tap water were freely available. Sham operation or hypophysectomy by the standard parapharyngeal approach (Smith, 1930) was performed when the animals were 59 days old using ketamine chloride (Ketalar: Parke-Davis, Detroit, MI, U.S.A.), $150 \mathrm{mg} / \mathrm{kg}$ i.p., as an anaesthetic. Completeness of hypophysectomy was determined by recording weight gain during a 1-week observation period before starting replacement therapy. Ether was used as an anaesthetic when osmotic minipumps were implanted and when intramuscular injections were given on the 10th day of the experiment. During the experiment (Days 3, 9 and 13) blood samples ( $300 \mu 1)$ were taken by tail-vein cut. The animals were killed by decapitation on the 17th day of the experiment and trunk blood was collected in chilled heparinized tubes. Plasma was separated and stored at $-30^{\circ} \mathrm{C}$ until assayed.

Hormonal treatment. Hormonal therapy began at 68 days of age, i.e. on the 10th day after surgery. Human growth hormone (hGH: Somatonorm, $2.3 \mathrm{i} . u . / \mathrm{mg}$; AB KABI, Stockholm, Sweden) was a generous gift from the manufacturer. The hormone was diluted in saline $(9 \mathrm{~g} \mathrm{NaCl} / \mathrm{l})$ and given in a daily dose of $1.4 \mathrm{i} . \mathrm{u} . / \mathrm{kg}(350 \mathrm{mu} / \mathrm{rat})$. Administration was performed either as two daily injections (at $12 \mathrm{~h}$ intervals) in volumes of $0.2 \mathrm{ml}$ s.c. or as a continuous infusion by means of Alzet osmotic minipumps (Alza Corp, Palo Alto, CA, U.S.A.) implanted s.c. on the back of the animals. The minipumps had a filling volume of $240 \mu \mathrm{l}$ and an estimated pumping rate of $1 \mu \mathrm{l} / \mathrm{h}$ at $37^{\circ} \mathrm{C}$. Oestradiol valerate (Progynon Depot: Schering, Berlin, W. Germany) was diluted in sesame oil and $0.2 \mathrm{ml}(1.5 \mathrm{mg} / \mathrm{kg} /$ 15 days) was given i.m. as a single injection. All hypophysectomized rats received replacement therapy with Lthyroxine (Sigma Chemical Co., St Louis, MO, U.S.A.; $10 \mu \mathrm{g} / \mathrm{kg} / \mathrm{day}$ ) and hydrocortisone acetate (Hydrocortal: Organon Ltd, Göteborg, Sweden; $500 \mu \mathrm{g} / \mathrm{kg} / \mathrm{day}$ ). L-Thyroxine and hydrocortisone acetate were diluted with saline and given in a volume of $0 \cdot 2 \mathrm{ml} \mathrm{s.c.} \mathrm{at} \mathrm{08:00} \mathrm{h} \mathrm{daily.} \mathrm{The} \mathrm{rats} \mathrm{were} \mathrm{treated} \mathrm{according} \mathrm{to} 5$ different protocols as shown in Table I.

Antisera. Rabbit anti-rat albumin was obtained from Cappel Laboratories (Worthington, U.S.A.). Goat antiPAMP-1 was kindly supplied by Dr Jann Hau (Institute of Veterinary Pathology, University of Copenhagen, Denmark). Goat anti-rat acute phase $\alpha_{2}$-macroglobulin was kindly provided by $\operatorname{Dr} \mathrm{F}$. Lorscheider (Department of Medical Physiology, University of Calgary, Canada).

Table 1. Treatment regimen and number of animals in the different experimental groups

\begin{tabular}{clc}
\hline Group & \multicolumn{1}{c}{ Treatment } & $\begin{array}{c}\text { No. of } \\
\text { rats }\end{array}$ \\
\hline A & Sham & 5 \\
B & Hx only & 6 \\
C & Hx + E $_{2}$ & 7 \\
D & Hx + hGH continuous infusion & 6 \\
E & Hx + hGH 2 s.c. injections/day & 6 \\
\hline
\end{tabular}

$\mathrm{Hx}=$ hypophysectomy; $\mathbf{E}_{2}=$ oestradiol-17 $\beta ; \mathrm{hGH}=$ human growth hormone. 
Quantitative immunoassays. Rat serum proteins were quantified by rocket immunoelectrophoresis (Laurell, 1972) in $1 \%(\mathrm{w} / \mathrm{v})$ agarose (Litex, Copenhagen, Denmark) in $0.1 \mathrm{M}-$ Tris-barbital buffer $\mathrm{pH} 8.8$, at $2.5 \mathrm{~V} / \mathrm{cm}$ for $15 \mathrm{~h}$. Suitable dilutions of the antibody concentration were $50-200 \mu 1 / 15 \mathrm{ml}$ gel. Samples of $10 \mu 1$ were applied in each well and diluted: for albumin $1+500$ and for PAMP-1 up to $1+100$. Samples with zero concentration were checked in the assay undiluted. Samples for acute phase $\alpha_{2}$-macroglobulin determinations were applied without dilution. All values were expressed as percentage change from the values obtained on Day 3 , i.e. the first sample.

\section{Results}

A prompt decrease in circulating PAMP-1 concentrations was recorded in all hypophysectomized animals (Fig. 1). Mean values ( \pm s.d.) in the different groups on the 9 th day of the experiments were $14 \pm 4 \%$ for Group B, $14 \pm 3 \%$ for Group C, $9 \pm 8 \%$ for Group D and $9 \pm 10 \%$ for Group E of the reference level. During continuous hGH administration (Group D) mean PAMP-1 values were restored ( $103 \pm 35 \%$ on Day 13$)$ and even increased above the reference level (143 $\pm 37 \%$ on Day 17). In all other hypophysectomized animals, irrespective of treatment, PAMP-1 levels on Days 13 and 17 were undetectable. In sham-operated animals PAMP-1 concentrations were stable throughout the experiment.

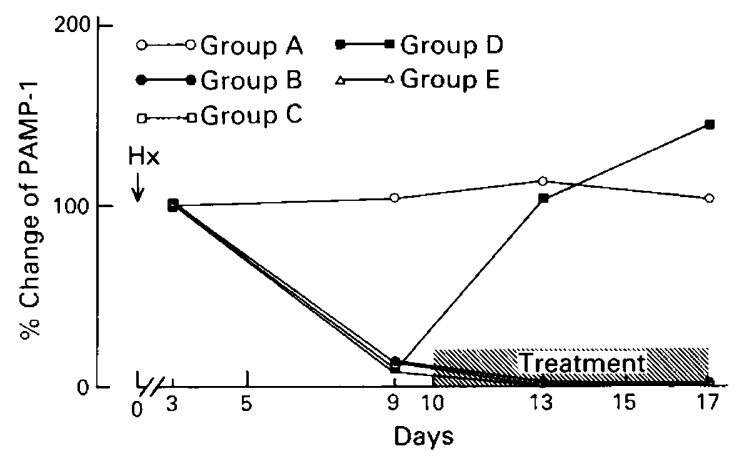

Fig. 1. Mean values for the serum concentrations of rat PAMP-1 in the five groups according to Table 1. Values are expressed as \% change from the values obtained on Day 3, i.e. the first sample. $\mathbf{H x}=$ hypophysectomy.

There were no changes in albumin concentrations after hypophysectomy or during oestrogen or hGH treatment (Fig. 2a). Serum concentrations of acute phase $\alpha_{2}$-macroglobulin were stable after hypophysectomy and during oestrogen therapy, but increased above the reference level during continuous $(183 \pm 37 \%$ on Day 13 and $153 \pm 39 \%$ on Day 17$)$ and intermittent hGH administration ( $185 \pm 17 \%$ on Day 13 and $177 \pm 28 \%$ on Day 17) (Fig. 2b).

\section{Discussion}

The importance of pituitary function as regards the stimulatory influence of oestrogens on PAMP1 levels has previously been reported (Hau et al., 1983; Fröhlander et al., 1987). Oestrogen treatment had no effect on the plasma concentration of this protein in hypophysectomized animals. In the present study continuous infusion of hGH had a rapid and marked stimulatory effect whereas the same dose of hGH given as two daily injections was ineffective. These results clearly indicate a role for the sexually dimorphic secretory pattern of GH in the regulation of PAMP-1. In the rat oestrogens increase basal GH secretion while androgens decrease basal trough values between 


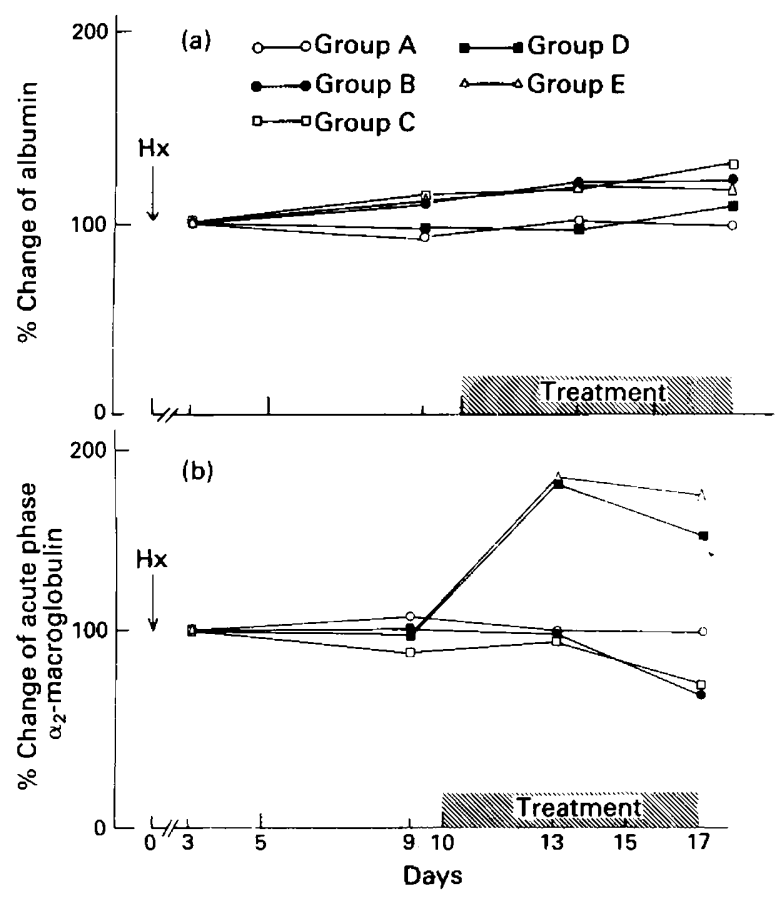

Fig. 2. Mean values for the changes in serum concentration of (a) albumin and (b) acute phase $\alpha_{2}$-macroglobulin in the rats treated as indicated in Table 1 . All values are expressed as $\%$ change from the values obtained on Day 3, i.e. the first sample.

secretory peaks (Jansson et al., 1985). Oestrogens may exert their effect on PAMP-1 by increasing the basal serum level and 'feminizing' the secretory pattern of GH. Also the low concentrations of PAMP-1 in normal male rats (Carlsson-Bostedt et al., 1987) could be explained by an influence of testosterone on the secretory pattern of GH. The observation that serum concentrations of PAMP1 in castrated male mice were increased and similar to those of intact female mice (Hau et al., 1982) is in accordance with this hypothesis. It is well established that gonadectomy in male rats results in increased basal concentrations of GH (Jansson et al., 1985).

Subcutaneous injections every $12 \mathrm{~h}$ were used to mimic the secretory pattern of GH in the adult male rat. Previous studies (Mode et al., 1981) have revealed a 'feminizing' effect when GH was given every 3 or $6 \mathrm{~h}$ which was similar to the effect of continuous infusion. On the other hand there was no 'feminizing' influence when the same dose of GH was given subcutaneously at 12-h intervals. The results from measurements of plasma $\mathrm{GH}$ concentrations after s.c. injections show that when GH is given every $12 \mathrm{~h}$, but not every 3 or $6 \mathrm{~h}$, the plasma concentrations will be very low or undetectable for several hours between the injections (Jansson et al., 1982). The present regimen in hypophysectomized female animals should therefore mimic at least one important aspect of the normal male secretory pattern. Human GH binds both to somatogenic and lactogenic receptors in the rat liver (Postel-Vinay, 1976). However, when prolactin was given to hypophysectomized mice there was no effect on the serum concentration of PAMP-1 (Hau et al., 1983). It therefore seems unlikely that the present results could be explained by an interaction of hGH with lactogenic receptors.

Albumin levels are generally unaffected by sex steroid administration and pregnancy (Laurell \& Rannevik, 1979) and there are no reports on sex differences in the production of this protein. 
Albumin concentrations were unchanged in all groups during the experiment, and this is in accordance with previous studies (Carlsson-Bostedt et al., 1987). The acute phase $\alpha_{2}$-macroglobulin of the rat is known to increase during pregnancy but is unaffected or suppressed by oestrogen administration (Bell, 1980). In the present study an increase was recorded during hGH substitution irrespective of the mode of administration, but no effect of hypophysectomy could be detected. A non-specific stimulation of $\mathrm{hGH}$ or an acute phase response due to the parenteral administration of a foreign protein could be possible explanations of this finding.

According to classical theory oestrogen effects are mediated via specific receptors. The presence of such molecules in rat liver has been demonstrated and suggested to mediate direct oestrogen effects on the production of serum proteins like renin substrate (Eisenfeld et al., 1977). However, it is unclear whether liver oestrogen receptors have a physiological role in mediating oestrogen action. The liver differs from typical target organs in that the given steroid is rapidly metabolized and excreted. The number of binding sites is about one half to one third of the normal receptor concentration in well known target organs such as the uterus (Powell-Jones et al., 1976). High doses of hormone are required to promote translocation to the nucleus and translocation is not accompanied by induction of a progesterone receptor (Eisenfeld \& Aten, 1982). The present results on PAMP-1 suggest that the apparent oestrogenic influence on this protein is more likely to be mediated via a modification of GH secretion than a direct effect upon protein synthesis in the liver or other tissues.

This work was supported by the Swedish Medical Research Council $(5982,8269$ and 1387), The Faculty of Medicine, University of Umea and Hans and Loo Osterman's Foundation. We thank Mrs M. Isaksson, Ms E. Näslund and Mrs M. Wallén for technical assistance and Mrs V. Enqvist for excellent typing.

\section{References}

Bell, S.C. (1980) Effects of oestradiol and progesterone on the concentration of $\alpha_{2}$-macroglobulin in the sera of injured male and female rats. J. Endocr. 86, 189-191.

Carlsson-Bostedt, L., Fröhlander, N., Edén, S., Stigbrand, T. \& von Schoultz, B. (1987) Effects of oestrogen and human growth hormone on pregnancy-associated plasma proteins in the rat. Acta endocr., Copenh. 116, 299-304.

Carlsson, L., Folkerssen, J. \& Stigbrand, T. (1985) Antigenic determinants of pregnancy-associated $\alpha_{2}$ glycoprotein and $\alpha_{2}$-macroglobulin defined by poly- and monocional antibodies. Molec. Immunol. 22, 1073-1080.

Edén, S. (1979) Age and sex-related differences in episodic growth hormone secretion in the rat. Endocrinology $105,555-560$.

Eisenfeld, A.J. \& Aten, R.F. (1982) Estrogen receptor in the mammalian liver. In The Endocrines and the Liver, pp. 49-62. Eds M. Langer, L. Chiandussi, I. J. Chopra \& L. Martini. Academic Press, London.

Eisenfeld, A.J., Krakoff, L.R. \& Aten, R.F. (1977) Developmental correlation of higher levels of estrogen binding by macromolecules in rat liver supernatant and of increases in plasma renin substrate levels after estrogen administration. Biochem. Pharmacol. 26, 923-927.

Fröhlander, N., Gidley-Baird, A.A., Hau, J. \& von Schoultz, B. (1987) Effects of growth hormone on pregnancy-associated murine protein-1. J. Reprod. Fert. 77, 367-371.
Hau, J. \& Porstmann, T. (1984) Characterization of the analogues to human pregnancy-associated $\alpha_{2}$-glycoprotein $\left(\alpha_{2}-\mathrm{PAG}, \mathrm{PZP}\right)$ isolated in the mouse and rat. Lab. Anim. 18, 344-348.

Hau, J., Svendsen, P., Teisner, B. \& Grudzinskas, J.G. (1982) Regulation of pregnancy-associated murine protein- 1 by gonadal steroids. J. Reprod. Fert. 66, 273-275.

Hau, J., Gidley-Baird, A.A., Teisner, B., Svendsen, P. \& Westergaard, J.G. (1983) The influence of pituitary and gonadal hormones on serum levels of pregnancyassociated murine protein-1. Acta endocr., Copenh. $104,23-26$.

Jansson, J-O., Albertsson-Wikland, K., Edén, S., Thorngren, K-G. \& Isaksson, O. (1982) Effect of frequency of growth hormone administration on longitudinal bone growth and body weight in hypophysectomized rats. Acta physiol. scand. 114, $261-265$.

Jansson, J-O., Edén, S. \& Isaksson, O. (1985) Sexual dimorphism in the control of growth hormone secretion. Endocr. Rev. 6, 128-150.

Laurell, C.B. (1972) Electroimmunoassay. Scand. J. Clin. Lab. Invest., Suppl. 124, 21-37.

Laurell, C.B. \& Rannevik, G. (1979) A comparison of plasma protein changes induced by danazol, pregnancy and estrogens. J. clin. Endocr. Metab. 49, 719-725.

Mode, A., Norstedt, G., Simic, B., Eneroth, P. \& Gustafsson, J.§. (1981) Continuous infusion of 
growth hormone feminizes hepatic steroid metabolism in the rat. Endocrinology 108, 2103-2108.

Norstedt, G. (1982) A comparison between effect of growth hormone on prolactin receptors and estrogen receptors in rat liver. Endocrinology 110, 2107-21 12.

Postel-Vinay, N-C. (1976) Binding of human growth hormone to rat liver membranes: lactogenic and somatotrophic sites. FEBS Lett. 69, 137-140.

Powell-Jones, W., Davies, P. \& Griffiths, K. (1976) Specific binding of $\left({ }^{3} \mathrm{H}\right)$-oestradiol by cytoplasmic protein components of female rat liver. J. Endocr. 69, 167-168.

Sand, O., Folkersen, J., Westergaard, J.G. \& SottrupJensen, L. (1985) Characterization of human pregnancy zone protein. Comparison with human $\alpha_{2}-$ macroglobulin. J. biol. Chem. 260, 15723-15735.

Sarcione, E.J., Delluomo, D., Zloty, M.\& Biddle, W. (1986) Tissue and cellular sites of pregnancy associated alpha ${ }_{2}$-glycoprotein $\alpha_{2}$ PAG) synthesis in pregnant rats. In Pregnancy Proteins in Animals, pp. 379-387. Ed. J. Hau. Walter de Gruyter, Berlin.

Smith, P.E. (1930) Hypophysectomy and replacement therapy in the rat. Am. J. Anat. 45, 205-273.

Tannenbaum, G.S. \& Martin, J.B. (1976) Evidence for an endogenous ultradian rhythm governing growth hormone secretion in the rat. Endocrinology 98, 562-570.

von Schoultz, B. \& Stigbrand, T. (1982) Pregnancy zone protein: chemistry, biology and clinical studies. In Pregnancy Proteins, pp. 167-175. Eds J. G. Grudzinskas, B. Teisner \& M. Seppälä. Academic Press, Sydney.

Waites, G.T. \& Bell, S.C. (1986) Pregnancy proteins and the acute-phase response. In Pregnancy Proteins in Animals, pp. 195-212. Ed. J. Hau. Walter de Gruyter, Berlin.

Received 1 December 1987 